\title{
HISTORY AND CULTIVATION OF PARMA VIOLETS (VIOLA, VIOLACEAE) IN THE UNITED KINGDOM AND FRANCE IN THE NINETEENTH CENTURY
}

\author{
Luís Mendonça de Carvalho, ${ }^{1,2}$ Francisca Maria Fernandes, ${ }^{3}$ \\ Maria de Fátima Nunes, ${ }^{3}$ João Brigola, ${ }^{3}$ Nathalie Casbas, ${ }^{4}$ and Clive Groves ${ }^{5}$
}

\begin{abstract}
Scented cultivars of Parma violets were among the most important urban plants during the nineteenth century, with many references in literature, fashion, art and flower trade. Our research analyzed data related to Parma violets in France and in the United Kingdom and presents the cultivars introduced during the nineteenth century.
\end{abstract}

Keywords: Parma violets, Viola cultivars, United Kingdom, France, social history

The first records describing the use of violets (Viola L., Violaceae) in Europe are from Ancient Greece: fragrant violets were sold in the Athenian agora; praised by Greek poets, as in the writings of Sappho (Jesus, 2009); used in medicine (Theophrastus, 1916); had an active role in myths, such as in the abduction of Persephone (Ovid, 1955; Grimal, 1996); were used in garlands (Goody, 1993) and present in the Odyssey's garden of Calypso (Homer, 2003). They continued to be used throughout the Middle Ages and were present in Renaissance herbals (Cleene and Lejeune, 2002). In Renaissance paintings and in the Christian traditions, violets were commonly associated with the Virgin Mary and had a symbolic meaning connected with humility (Levi D'Ancona, 1977; Impelluso, 2004).

The genus Viola has circa 400 species (91 in Europe) and Parma violets are a morphologically well-defined group within the genus that, in ideal conditions, can produce fragrant flowers for seven consecutive months and rarely produce seeds (Coombs, 2003; Mabberley, 2008). They have been cultivated in Europe for centuries and several hypotheses tried to explain their origin. Earlier Italian literature from the XVI century refers to violets with a strong fragrance and pleiomerous flowers that were obtained from the East, near the city of Constantinople (now Istanbul), capital of the former Byzantine Empire. These texts describe violets that looked like roses, probably referring to ancestral plants of the contemporary Parma violets (Malécot et al., 2007). In Naples (Italy), a local tradition proposes that these violets came from Portugal, brought by the Bourbon royal family during the XVIII century; hence the local name Violetta Portoghese (Portuguese violet). Violets were taken from Naples to Parma, where they got the classic vernacular name, and from Parma to all other locations in Europe (Perfect, 1996; Robinson and Snocken, 2002). In 2007, Malécot et al. using ITS (Internal Transcribed Spacer) sequence variation and allozyme variation in fourteen putative loci concluded that cultivars of Parma violets belong to the genetic pool of Viola alba Besser subsp. dehnhardtii (Ten.) W. Becker, with parental plants from the Eastern and Western Mediterranean region, probably from Turkey and Italy.

This research was sponsored by FCT-Portuguese Science Agency TDC/HIS-HCT/111048/2009. We are grateful to Her Majesty Queen Elizabeth II for permission to use the excerpt from Queen Victoria's diary, Pamela Clark (Royal Archives, Windsor Castle), Hélène Vie (La Maison de la Violette, France), William Hornby (Seaside Plants, UK), Patrick Hockey (David Glenn's Lambley Nursery, Australia), Giancarlo Sibilio (Orto Botanico di Napoli, Italy) and Thierry Espitalier.

${ }^{1}$ Museu Botânico, Instituto Politécnico de Beja, Rua Pedro Soares, 7800-295 Beja, Portugal

${ }^{2}$ Author for correspondence: museu@ipbeja.pt

${ }^{3}$ Centro de Estudos de História e Filosofia da Ciência, Universidade de Évora, Largo do Marquês de Marialva, 8, 7000554 Évora, Portugal.

${ }^{4}$ Keeper of the French National Violet Collection, 4 Route de Villemur, 31620 Villaudric, France.

${ }^{5}$ Keeper of the United Kingdom National Violet Collection, Groves Nursery, West Bay Road, Bridport, Dorset, United Kingdom. 
Although Parma violets were cultivated in several European countries during the nineteenth century, among them Italy (Udine) and Germany, it is in French and British nursery catalogues that we find more data related to the production of Parma violets and to the introduction of new cultivars (Coon and Giffen, 1977; Coombs, 2003). In the United States of
America, violet nurseries were established along the East Coast (New England) and in California (near San Francisco) but the village that became closely associated with the history of violets in the U.S. was Rhinebeck (New York) where the cultivars Viola 'Marie Louise' and Viola 'Lady Hume Campbell' became widely grown (Galloway, 1914; Coon and Giffen, 1977).

\section{Parma Violets in France}

In France, the name Violette de Parme (Parma violets) is mentioned in Le Bon Jardinier (1805) but it may be older (Perfect, 1996). At the beginning of the nineteenth century, in the gardens of the Châteaux de Malmaison, near Paris, the Empress of France, Joséphine de Beauharnais (1763-1814), wife of Napoleon Bonaparte, cultivated Parma violets among many European and exotic plants that she collected over the years (Lack, 2004). In 1814 , Napoleon abdicated and was banished to the island of Elba; however, before leaving, he told to his followers that he would return when the violets were again in season. As a result of this statement, violets became a symbol that his supporters recognized. When he finally escaped and reappeared in Paris, in March 20th 1815, he was presented with a bouquet of violets and called Le Père La Violette. After his final defeat at Waterloo (1815) and the restoration of Louis XVIII to the French throne, violets became a symbol of sedition (Mendonça de Carvalho, 2011). Napoleon was exiled to the Island of Saint Helena and the Duchy of Parma was given to his second wife, Marie Louise, a member of the Hapsburg Austrian dynasty who, once at Parma, patronized violet fashion and trade (Sandrini, 2008). Later in the century, violets, especially Parma violets, regained the favors of the French Royal House under the Second Empire (1852-1870) ruled by Napoleon III (1808-1873) and his Spanish wife, Eugenia de Montijo (1826-1920). When the imperial couple were forced into exile in England, they took with them their passion for Parma violets and this increased the status of Parma violets in the United Kingdom (Coombs, 2003).

In France, during the nineteenth century, Parma violets were cultivated in three main areas: Paris, Toulouse and Côte d'Azur (French Riviera). They were sold as pot plants, cut flowers and for the industry of perfumes (although in the nineteenth century industry began to use ionone, a molecule that resemble the violet fragrance and was isolated from the roots of Iris x germanica L. var. florentina (L.) Dykes) (Nanneli, 2001; Coombs, 2003, Mabberley, 2008).

\section{Cultivation of Parma Violets in Paris}

In Paris, at the end of the XVIII century, cultivation of Parma violets was made in frames, within private houses and for private use. Violets sold on the streets were from other species, and were picked in the wild or from small-scale cultivation. Around 1830, some cultivators grew Parma violets in heated conditions but on a small-scale and were unable to provide sufficient flowers for trade. This condition changed in later years and, around 1840, Parma violets were regularly offered on sale but only one pale blue-mauve cultivar was available. During the Second Empire (1852-1870), bouquets of Parma violets became fashionable at evening receptions, balls, and the opera. In the decade of 1870, a cultivar with dark blue flowers known as Viola 'Marguerite de Savoie' or Viola 'Marie Louise' (the latter name prevailed) was introduced and became very popular. The neighbourhoods of Paris where Parma violets were cultivated included Sceaux, Verrières, Belleville, Montreuil, and Bourg-la-Reine. It was in Bourg-la-Reine village that the famous nursery of Armand Joseph Millet (1845-1920) was located. In 1898, describing the importance of Parma violets in Paris, Armand Joseph Millet wrote: "everyone who has lived in Paris, even those who have merely passed through the city in March or April, have seen and admired those beautiful pots of violets which adorn our florist's shops. All the covered markets and street markets are filled with them, flattering the eyes and filling the air of the metropolis with their sweet perfume. Well, it is the Parma violet again that supplies these quantities of plants." (Millet, 1898). It is estimated that at the beginning of 
the 1880 's, circa six million violets bunches were sold every year in Paris. Foreign countries, such as England, Belgium, Germany, Austria, and even Russia were dependent on the French violets from Paris and Southern France (Perfect, 1996; Coombs, 2003).

\section{Cultivation of Parma Violets in the Côte d’Azur}

In France, Parma violets were first cultivated in south of the country, and by the last quarter of the nineteenth century they were grown in olive orchards, as a secondary crop (Fig. 1), or as a main crop in open fields with partial shade (Fig. 2). These violets fulfilled the demand for cut violets from the European royalty, the aristocracy and other visitors to the Riviera who
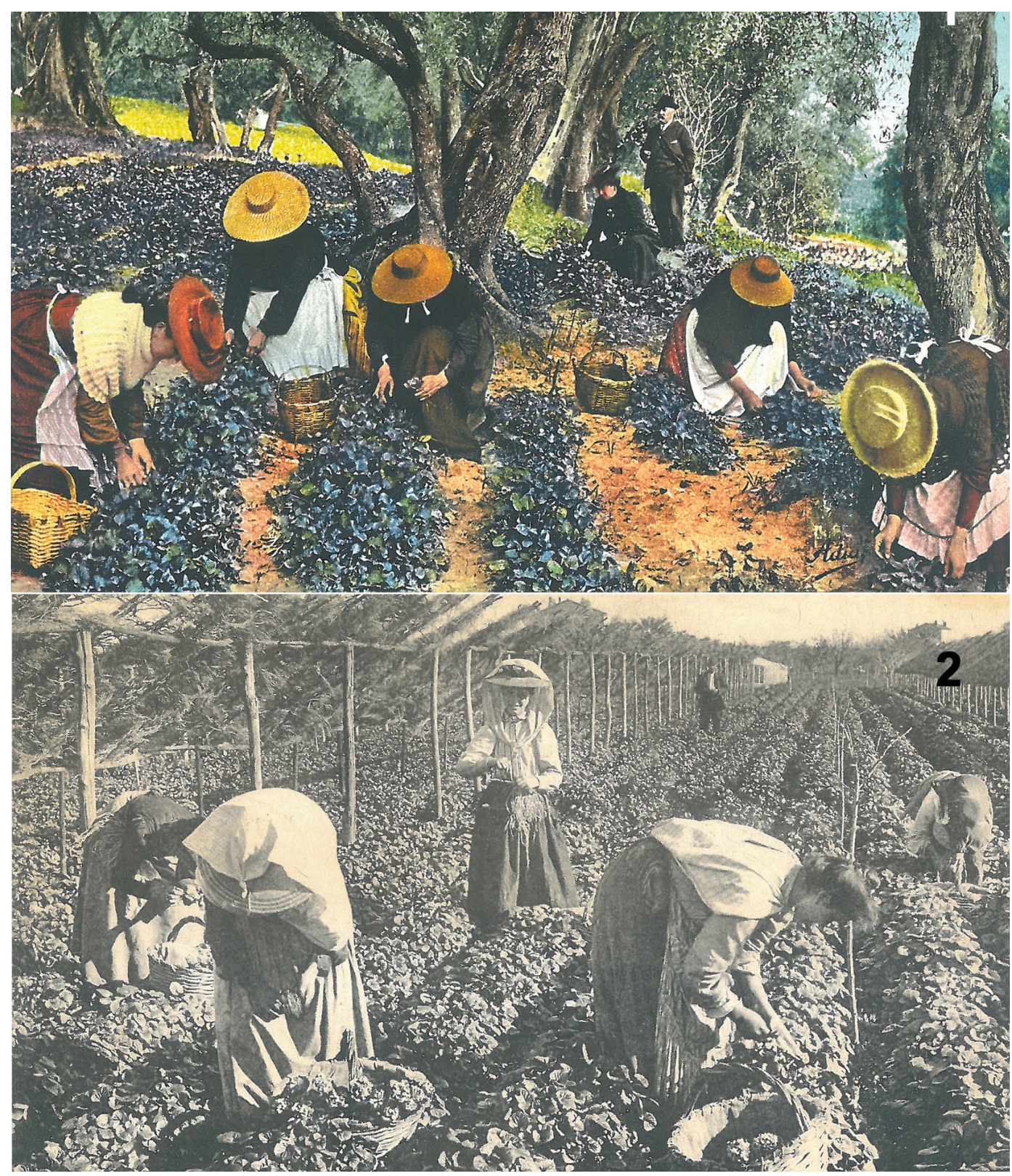

FIGURE 1. Violet plants growing in olive orchards (end of the nineteenth century postcard, Côte d'Azur).

FIGURE 2. Picking violets for bouquets (end of the nineteenth century postcard, Côte d'Azur). 
had followed the fashion of Queen Victoria. After visiting Menton, in 1882, the Queen decided to spend several weeks every yer on the Riviera, and thus reinforce the region as a high-class tourist destination (Coombs, 2003; Nelson, 2007).

Violet flowers and leaves were also used in the perfume industries located at Grasse for producing violet based perfumes. By the end of the century, and after a disease that seriously affected Parma violets, the Côte d'Azur farmers began to grow Viola odorata L. 'Victoria' instead of Parma violets. This bluishviolet cultivar probably is the one introduced by Armand Joseph Millet in 1878, and then named 'Czar Blue' which, in turn, had resulted from the historic violet Viola odorata L. 'The Czar'(Perfect, 1996; Nanneli 2001).

\section{Cultivation of Parma Violets in Toulouse}

In the Toulouse region, Parma violets were probably first cultivated in the village of Saint-Jory and then extended to other northern neighborhoods of Toulouse, especially to the villages of Lalande and Aucamville. The first quoted presence of Parma violets in Toulouse dates from 1854 (Timbal-Lagrave, 1862; Bertrand and Casbas, 2001). Local traditions affirm that violets were originally brought back to Toulouse from Italy by men who had fought in the French army during the middle nineteenth century wars. By the end of the nineteenth century, Parma violets cultivated near Toulouse were sold in the city markets and sent to other major French cities, including Paris. This cultivar has very long flower stalks which are very appreciated for making bouquets (Fig. 3). Parma violets from Toulouse were also used to make crystallised violets which were consumed in France and exported to the United States of America; between 500 and 1000 flowers were needed to make one kilogram of sweets (Perfect, 1996).

\section{Parma Violets in the United Kingdom}

In the United Kingdom, from the late eighteenth century to the middle of the nineteenth century, all major centers for the cultivation of violets were located at the county of Middlesex, near London. As the development of London claimed new lands, violet nurseries were established in the counties of Kent, Sussex and Devon. Parma violets were already known in 1816, when Sir Joseph Banks (President of the Royal Society, plant collector and unofficial director of Kew Gardens under King Georg III) had them cultivated in three hundred pots at his garden in Spring Grove House, Isleworth (Farrar, 1989). During the first half of the nineteenth century, Parma violets cultivated in United Kingdom were all from the cultivar known as Viola 'Pallida Plena' or Viola 'Suavis Pallida Plena Italica', probably the original Parma violet now called Viola 'Neapolitan' (Fig. 4). In 1873, the new violet called 'de Parme.' listed by the British nurseries, probably was the cultivar Viola 'Duchesse de Parme' which had come from Florence (Italy) three years earlier. In 1875, the cultivar Viola 'Lady Hume Campbell' was introduced in the British markets and got the name of the woman who had brought it from Milan (Italy) and who had grown it in Pinner (Middlesex, UK). This latter cultivar had a long flowering period (up to May) and could produce many flowers (100 plants could yield 600 to 1000 flowers weekly). In 1880, a white Parma violet appeared in the market, Viola 'Swanley White' introduced by the Swanley Nurseries, in Kent (United Kingdom). This violet was purchased from the Italian Count Filippo di Brazza, who had raised it in Udine (Italy) (Coombs, 2003). The association of violets with the ruling classes and the aristocracy was very strong during the final decades of Queen Victoria's reign and during the reign of Edward VII, when the gardens of Windsor Castle were supervised by John Dunn and circa 3000 violets where cultivated in pits protected with frames. Only three cultivars were grown, : two were Parma violets (Viola 'Marie Louise' Louise' and Viola 'Lady Hume Campbell'); the other one was Viola odorata L. 'Princess of Wales' Wales' (Cuthbertson, 1910). Queen Victoria (1819-1901) had a long association with violets; in the diary that she kept all her life, the first reference to violets was made when she was still a princess, on the Easter Day of 1834: "Mamma gave me two very pretty little china baskets with violets..." (Queen Victoria, unpublished manuscript). 


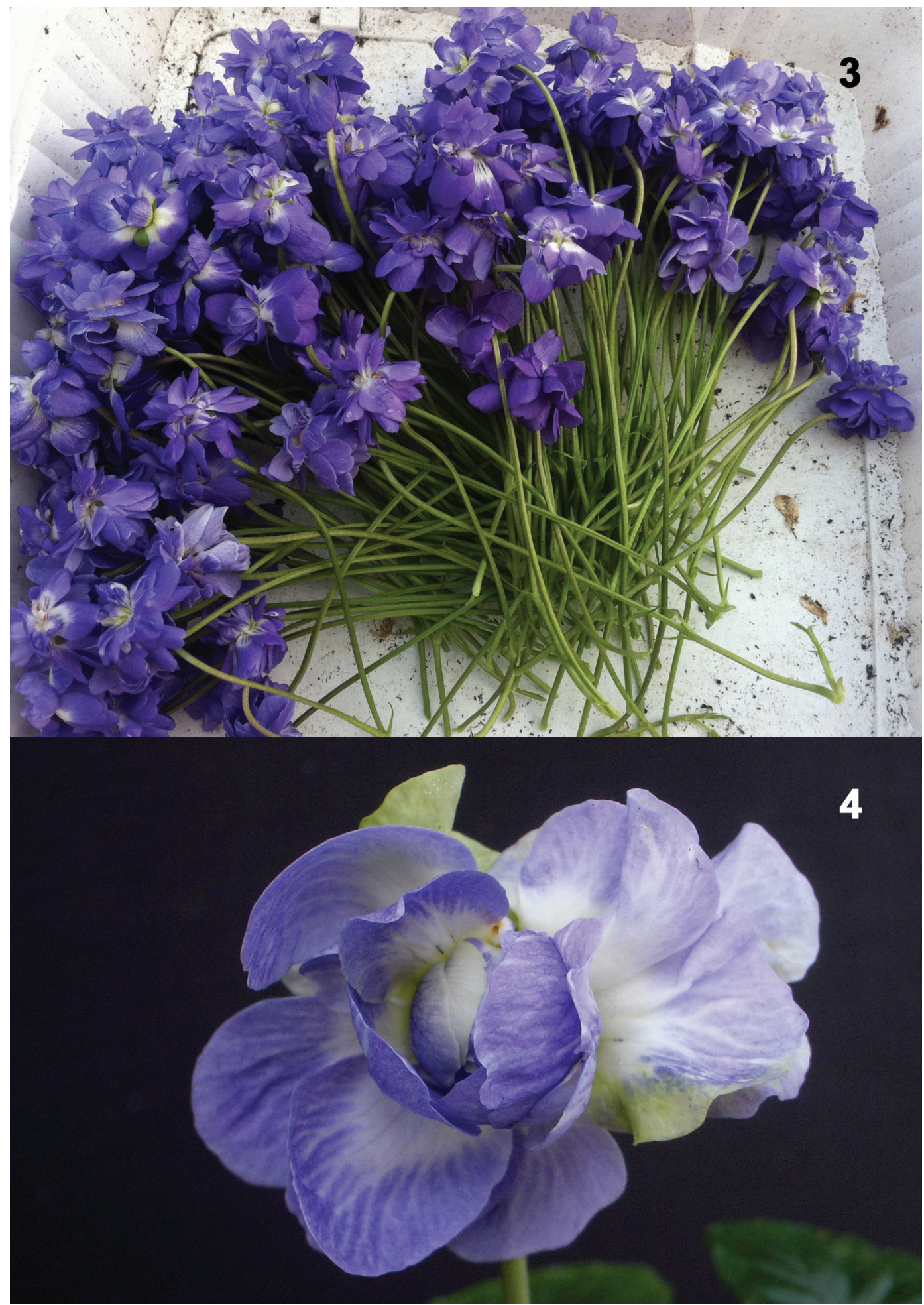

Figure 3. Fresh picked flowers of Viola 'Parme de Toulouse'. Photo by Hélène Vie. Figure 4. Viola 'Neapolitan'. Photo by Clive Groves.

Please combine these two figure captions. 


\section{Nineteenth Century Cultivars}

In the nineteenth century, at least twenty-five Parma violets cultivars were introduced in the French and British markets, nevertheless not all were kept in nursery catalogues. The following list describes the most cultivated and soughtafter cultivars. The dates indicate when the cultivars became available (Timbal-Lagrave, 1862; Perfect, 1996; Bertrand and Casbas, 2001; Coombs, 2003).
Viola 'Conte di Brazza' (1880) pure white flowers with slight blue tints (synonymous Viola 'Swanley White' or Viola 'White Parma'). This cultivar won the Royal Horticultural Society's First Class Certificate in 1883 (Fig. 5).

Viola 'Duchesse de Parme' (1870) pale lavender blue flowers; very prolific and probably the easiest to grow (Fig. 6).

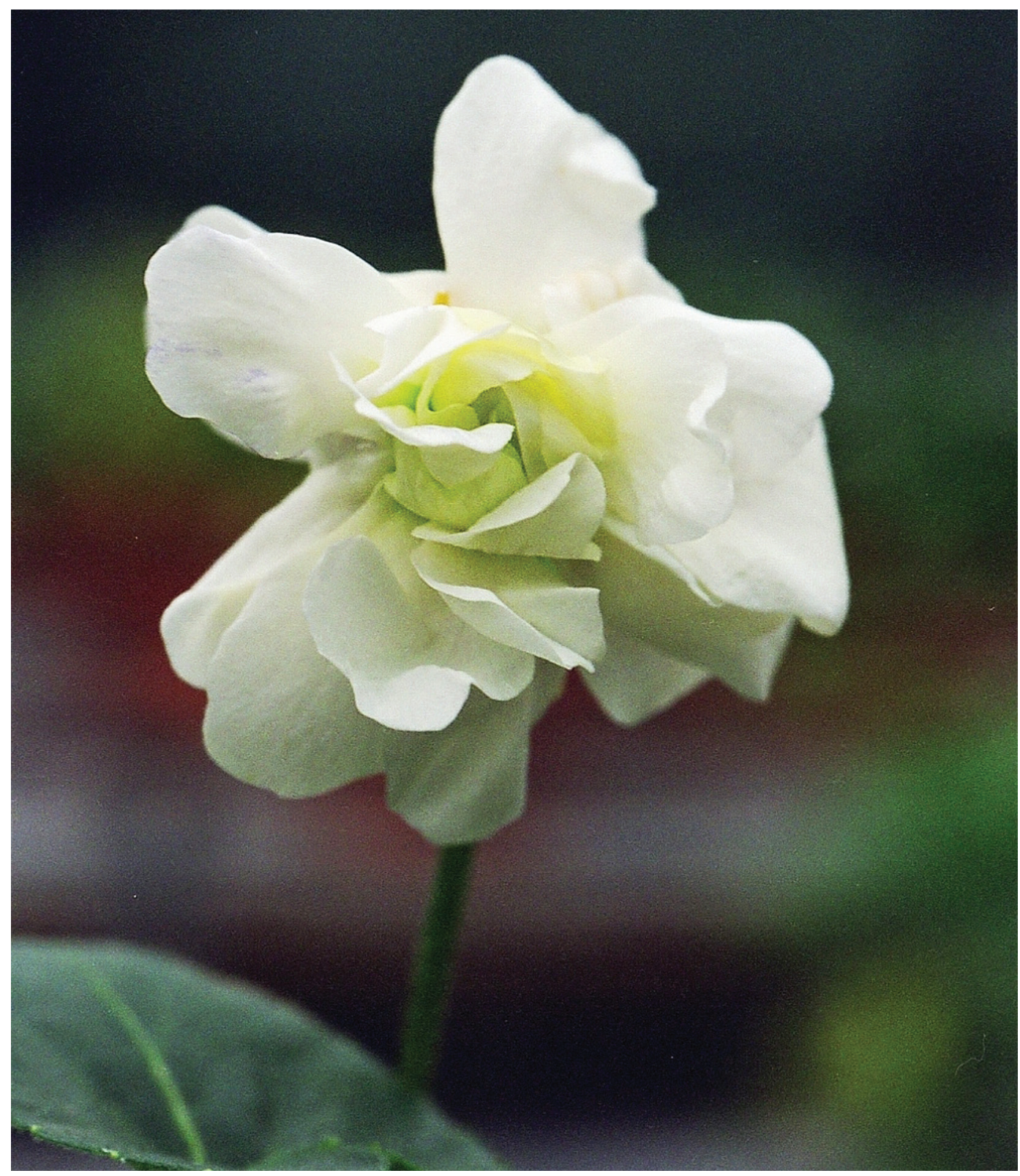

Figure 5. Viola 'Conte di Brazza'. Photo by Nathalie Casbas. 


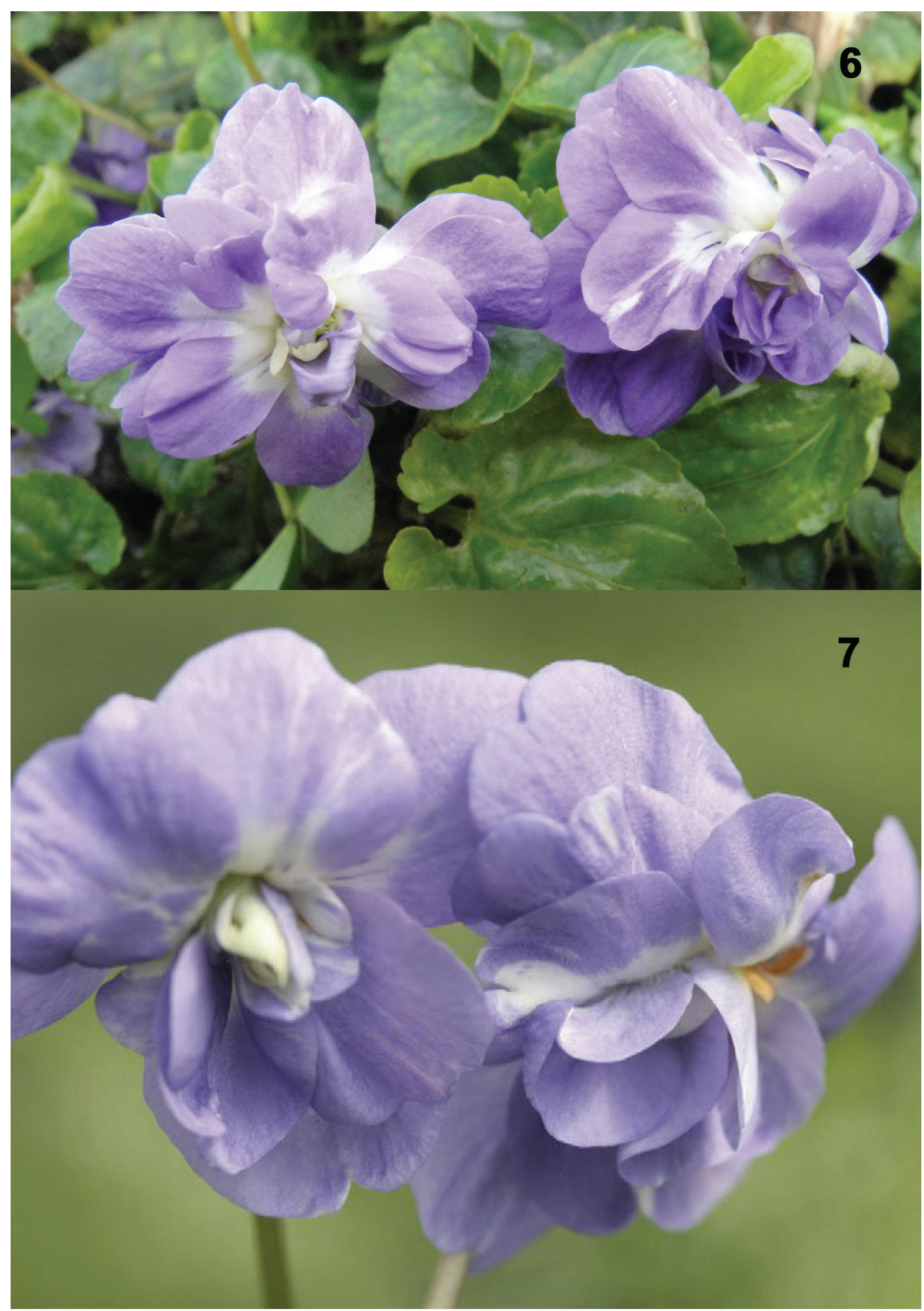

Figure 6. Viola 'Duchesse de Parma'. Photo by Clive Groves.

Figure 7. Viola 'Lady Hume Campbell'. Photo by Patrick Hockey.

Please combine these two figure captions. 
Viola 'Lady Hume Campbell' (1875) lavender mauve flowers (synonymous Viola 'Gloire d'Angoulême') (Fig. 7).

Viola 'Madame Millet' (1884) lilac rose flowers, slightly mauve, like little roses. This cultivar was obtained by Néant of Bièvres in Seine-et-Oise (1868), and introduced by the famous French nursery Millet et Fils of Bourg-la-Reine. It was a very popular cultivar in the nineteenth century but it is no longer available and is now probably extinct.

Viola 'Marie Louise' (1865, probably older) deep lavender mauve flowers (Fig. 8).

Viola 'Mrs. John J. Astor' (1895) rose lavender flowers. A cultivar originated in the USA that won the Award of Merit from the Royal Horticultural Society (1899); now a lost cultivar.

Viola 'New York' (1869) deep lavender mauve flowers, with red markings.

Viola 'Parme de Toulouse' (1854) mauve flowers with paler center, very prolific (Fig. 9).

The interest in Parma violets continued throughout the early years of the XX century, with the introduction of new cultivars, such as Viola 'Mrs. Arthur' (1902), Viola 'd'Udine' (1903), Viola 'Queen Mary' (1915), but after the First World War and the changes in fashion occurred in the 1920's and 1930's, it began to decrease and Parma violets have never recovered their former status.

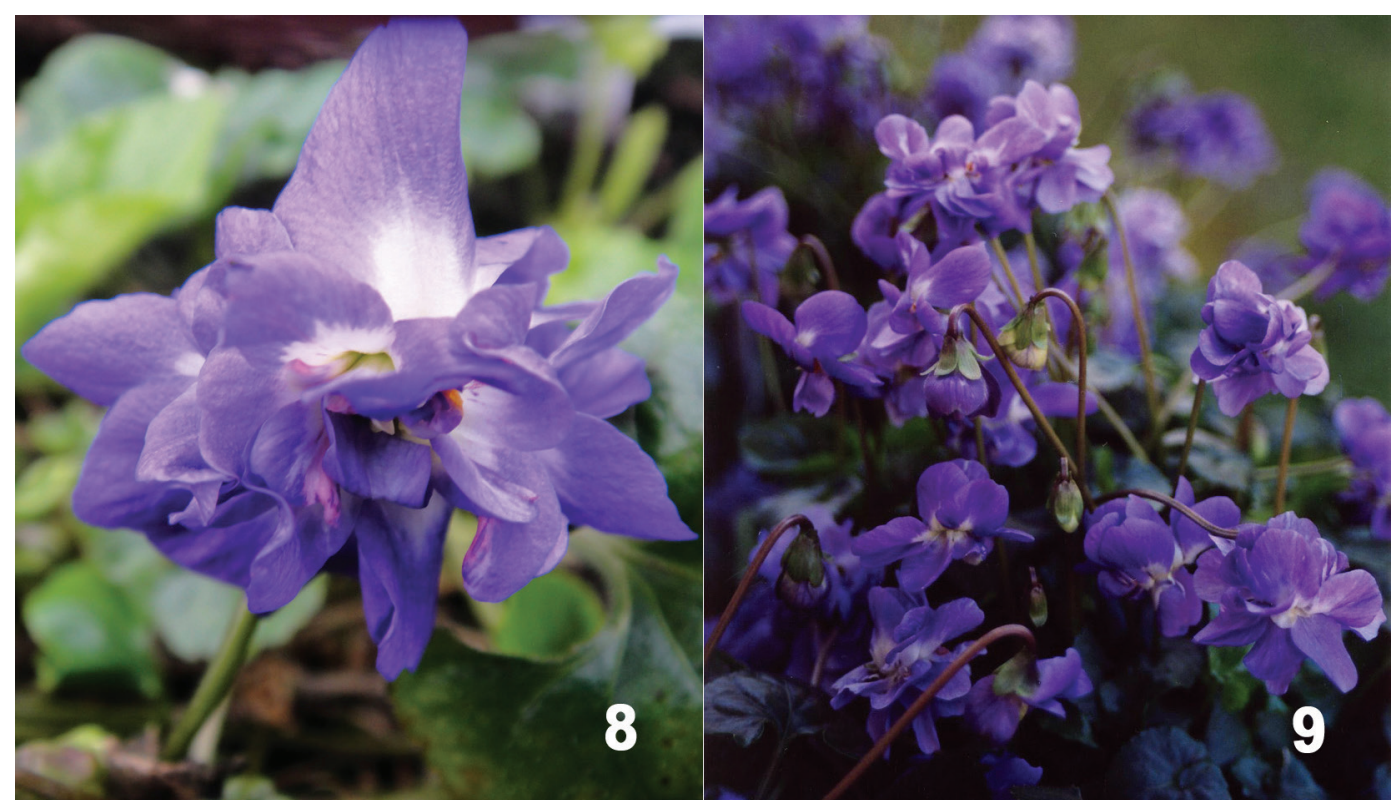

Figure 8. Viola 'Marie Louise'. Photo by Clive Groves.

Figure 9. Viola 'Parma de Toulouse'. Photo by Hélène Vie.

Please combine these two figure captions. 


\section{Literature Cited}

Bertrand, B., and N. Casbas 2001. Une Pensée Pour la Violette. Le Compagnon Végétal, vol. 11. Editions de Terran, Sengouagnet, France.

Cleenne, Marcel, and M. C. Lejeune 2002. Compendium of Symbolic and Ritual Plants in Europe, vol. 2. Man and Culture Publishers, Ghent, Belgium.

Coombs, Roy 2003. Violets: the History and Cultivation of Scented Violets. Batsford, London.

Coon, N., And G. GIFFen 1977. The Complete Book of Violets. A. S. Barnes and Company, New York.

Cuthbertson, W. 1910. Pansies, Violas \& Violets. T. C. \& E. C. Jack, London.

FARrar, E. 1989. Pansies, Violas and Sweet Violets. Hurst Village Publishing. Hurst, Berkshire.

Galloway, B. T. 1914. Commercial Violet Culture. A.T. De La Mare PTG. \& Pub. Co. Ltd, New York.

Goody, J. 1993. The Culture of Flowers. Cambridge, Cambridge University Press.

Grimal, P. 1996. The Dictionary of Classical Mythology. Blackwell Publishers, Ldt., Malden, MA.

Homer 2003. The Odyssey. E. V. Rieu, Trans., Penguin Classics, London.

Impelluso, L. 2004. Nature and Its Symbols. The J. Paul Getty Museum Publications, Los Angeles.

Jesus, C. 2009. Grinaldas de Violetas-Epítetos Derivados de Ion e Suas Valências na Poesia Grega. Humanitas 61: 31-57.

LACK, W. H. (ED.) 2004. Jardin de la Malmaison: Empress Josephine's Garden. Prestel, London.

Levi D'Ancona, M. 1977. The Garden of the Renaissance: Botanical Symbolism in Italian Painting. L. S. Olschki, Firenze, Italy.
Mabberley, D. 2008. Mabberley's Plant-Book, $3^{\text {rd }}$ Edition. Cambridge University Press, Cambridge.

Malécot, V., T. Marcussen, J. Munzinger, R. YockTeng, and M. HenRy 2007. On the Origin of the Sweet Smelling Parma Violet Cultivars (Violaceae): Wide Intraspecific Hybridization, Sterility, and Sexual Reproduction. Amer. J. Bot. 94(1): 29-41.

Mendonça de Carvalho, L. M. 2011. The Symbolic Uses of Plants. Pages 353-371 in E. ANDERSON, D. Pearsall, E. Hunn, and N. Turner, eds. Ethnobiology. Wiley-Blackwell, New York.

Millet. A. 1898. Les Violettes-Leurs Origines, Leurs Cultures. Librarie Agricole, Paris.

Nanneli, I. 2001. Viole. Idea Books, Milano, Italy.

Nelson, M. 2007. Queen Victoria and the Discovery of the Riviera. Tauris Parke Paperbacks, London.

Ovid 1955. Metamorphoses. R. Humphries, Trans., Indiana University Press, Bloomington.

Perfect, E. J. 1996. Armand Millet and His Violets. Park Farm Press, High Wycombe, UK.

Robinson, P. M., AND SNOCKEN, J. 2002. Checklist of the cultivated forms of the genus Viola including the register of cultivars. American Violet Society, Washington D.C.

SANDRINI, F. 2008. Maria Luigia e le Violette di Parma. Quaderni del Museo n.10, Museo Glauco Lombardi Fondazione Monte di Parma, Parma, Italy.

THEOPHRASTUS 1916. Enquiry into plants and minor works on odours and weather signs. SIR ARTHUR Hort, Trans., W. Heinemann, London.

Timbal-Lagrave, E. 1862. De la Culture de la Violette à Toulouse. Ann. Soc. Hort. Haute-Garonne 4: 1-6. 